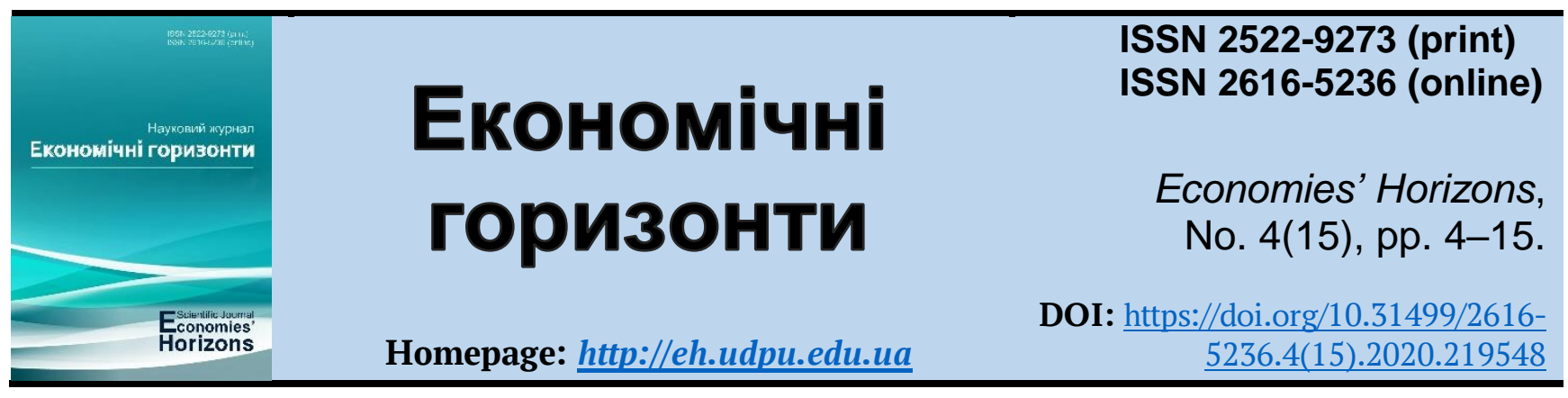

UDC [33+008]:1

\title{
An assessing the role of public financial policy in the field of culture
}

\author{
Iryna V. Zaichko ${ }^{1,2}$, Cand. Ec. Sc.
}

Received: 10 October 2020

Accepted: 27 November 2020
Zaichko, I. V. (2020), "An assessing the role of public financial policy in the field of culture", Economies' Horizons, no. 4(15), pp. 4-15. doi: https://doi.org/10.31499/26165236.4(15).2020.219548

Abstract. Purpose of the research. The main purpose of the article is to improve the methodological support for assessing the role of public financial policy in the field of culture. Methodology. The following methods, which used in the study: logical generalization, synthesis, induction and deduction, dialectical and system-structural methods, comparative analysis, graphical method, etc. Results. It is proved that due to the awareness of the role of culture in society, aspects of state activity to ensure the development of the economy in the field of culture are important. Public financial policy is one of the measures to increase the level of cultural competence of citizens. It is proposed to consider culture as a resource, bearing in mind that it becomes not only a costly area, but also the engine of the economy. Given that the sphere of culture around the world is built on a combination of budgetary and extrabudgetary funding, there are different activities, a significant amount of movable and immovable property, some of which is withdrawn from civil circulation or has restrictions on civil turnover (monuments, libraries, archival funds, museum collections, etc.). The sources of financing of cultural institutions in Ukraine and the distribution of expenditures of the Consolidated Budget of Ukraine for culture and art are analyzed. It is determined that the issues of preservation of cultural heritage should become a factor that will really affect the financial performance of cultural transformations in the country. Practical meaning. It is substantiated that the policy in terms of public funding of culture and art should be based on certain effective areas that reflect the real cultural needs of society. Prospects for further research of the author are to study the impact of budget policy on the state of Ukraine's cultural heritage.

Keywords: culture, state policy, financing, process, relations, financial support, budget.

JEL Classification: H82, O35, Z18.

Number of references: 33; number of tables: 1; number of figures: 2; number of formulas: $\mathbf{0 .}$

\footnotetext{
${ }^{1}$ National Academy of Statistics, Accounting and Audit; Associate Professor at the Department of Finances, Banking and Insurance; ORCID ID: https://orcid.org/0000-0002-6080-2959; e-mail: zkiv26@gmail.com.

${ }^{2}$ Educational and Scientific Institute of Kyiv National University of Culture and Arts.
} 


\title{
Оцінювання ролі державної фінансової політики у сфері культури
}

\author{
Ірина Володимирівна Заїчко ${ }^{1,2}$, к. е. н.
}

Стаття надійшла: 10.10 .2020 Статmя прийнята: 27.11.2020
Zaichko I. V. An assessing the role of public financial policy in the field of culture. Економічні горизонти. 2020. № 4(15). C. 4-15. DOI: 10.31499/2616$\underline{5236.4(15) .2020 .219548}$

Анотація. Мета дослідження. Головна мета статті полягає в удосконаленні методичного забезпечення оцінювання ролі державної фінансової політики у сфері культури. Методологія. У ході дослідження застосовано такі методи: логічного узагальнення, синтезу, індукції та дедукції, діалектичний і системно-структурний методи, порівняльний аналіз, графічний метод тощо. $P e-$ зультати. Доведено, що через усвідомлення ролі культури у суспільстві важливими є аспекти державної діяльності щодо забезпечення розвитку економіки в сфері культури. Державна фінансова політика є одним із заходів на шляху підвищення рівня культурної компетентності громадян. Запропоновано культуру розглядати як ресурс, маючи на увазі що вона стає не тільки витратною сферою, а й двигуном економіки. Зважаючи, що сфера культури в усьому світі побудована на поєднанні бюджетного і позабюджетного фінансування, у іiі межах є різні види діяльності, значний обсяг рухомого і нерухомого майна, частина якого виведена 3 цивільного обороту або має обмеження у цивільному обороті (пам’ятники, бібліотечні, архівні фонди, музейні колекції тощо). Проаналізовано джерела фінансування закладів культури в Україні та розподіл видатків Зведеного бюджету України на культуру та мистецтво. Визначено, що питання про збереження культурної спадщини повинні стати фактором, який реально впливатиме на фінансові показники культурних перетворень у країні. Практичне значення. Обгрунтовано, що політика в розрізі державного фінансування культури і мистецтва має базуватися на певних результативних напрямах які відображають реальні культурні потреби суспільства. Перспективи подальших досліджень автора полягають у дослідженні впливу бюджетної політики на стан культурної спадщини України.

Ключові слова: культура, державна політика, фінансування, процес, відносини, фінансове забезпечення, бюджет.

Кількість джерел: 33; кількість таблиць: 1; кількість рисунків: 2; кількість формул: 0.

\section{Introduction.}

Today in Ukraine, along with the revival of civil society, there is an awareness of the special role of culture in the state as a key object for solving the problem of developing the nation's intelligence and recognizing its information potential as a strategic resource for modernization. Significant changes in society have led to the activation of its members in various spheres of life: political, economic, financial, social. The level of cultural competence of citizens largely determines the development of economy and politics, national security and competitiveness of the country. Culture is one of the main guarantors of the country's importance in world public opinion. Therefore, in the period of globalization changes and transformations, the issue of developing an effective fiscal policy, which is based on measures to support the effective development of entities that organize their activities in the field of culture and education, becomes important.

The state is precisely that structural element of the system of formation and implementation of the control function in relation to

\footnotetext{
${ }^{1}$ Національна академія статистики, обліку та аудиту; доцент кафедри фінансів, банківської справи та страхування; ідентифікатор ORCID: https://orcid.org/0000-0002-6080-2959; e-mail: zkiv26@gmail.com.

${ }^{2}$ Навчально-науковий інститут Київського національного університету культури і мистецтв.
} 
the strategy of development of cultural and educational institutions. The priority of the functioning of state authorities and management in the field of culture, which the latter must address in cooperation with public institutions, cultural intelligentsia and prominent cultural figures, is to improve the principles and directions of cultural policy, which is of great strategic importance for development and modernization (Ihnatchenko, 2013, p. 3).

\section{Literature review.}

The works of many scientists are devoted to the problems of financing culture and understanding the role of the state in this process. Among the foreign authors who investigate the financing of the cultural sphere, we highlight the following: F. Nocca (2017), S. Lavezzolo, C. Rodríguez-Lluesma and M. Elvira (2018), M. Tian, P. Deng, Y. Zhang and M. Salmador (2018), A. Bayanova et al (2019), L. Csorba (2020) etc. This study is based on the work of domestic authors such as: O. Batishcheva (2007), Yu. Yakymets (2011), K. Dolomanova (2012), I. Ihnatchenko (2013), M. Khudolii (2013), V. Andrushchenko (2014), I. Dubok (2015) etc.

Many issues of research of financial and economic problems of culture are reflected in the literature, but there is a need to clearly define the role of culture in socio-economic development, justification of culture as an investment rather than an expenditure area; in the systematization of public services in the field of culture, in the scientific understanding of the feasibility of transforming public institutions into other organizational and legal forms as a way to improve the efficiency of budget funds.

\section{Methods.}

The following methods were used in the study: logical generalization, synthesis, induction and deduction, dialectical and systemstructural methods, comparative analysis, graphical method, etc.

\section{Research objectives.}

The main purpose of the study is to improve the methodological support for assessing the role of public financial policy in the field of culture.

\section{Results and discussions.}

It is important to understand the term "culture" as a method of forming a worldview, i.e. what can be used to formulate values, goals and objectives that will be accepted by citizens today and tomorrow. Culture provides an opportunity to form a picture of the world, a picture of how reality is understood and in what direction it should develop, to form the values of life of Ukrainians. In this direction, the issue of cultural development is a matter of strategic development of the country.

Many definitions of the term "culture" allow us to consider it as a multifaceted phenomenon (Table 1).

Culture is a creative set of all kinds of transformative activities of man and society, the result of their activities. It arose under the influence of social needs and demands. Human society needed the transfer and consolidation of spiritual values, and culture has become a cumulative means of preserving the accumulated spiritual values, which has become sustainable (Moisieieva and Usachov, 2013, p. 70).

According to the activity approach to understanding culture, it is defined as a set of material, practical and spiritual assets of society that reflect the level of its historical development, embodied in everyday human activity, are reflected in its social, moral, aesthetic and other characteristics (Honcharenko, 1997, p. 182).

As a historical imitation - it is a set of socially acquired and transformed from generation to generation significant symbols, ideas, values, customs, beliefs, traditions, norms and rules of conduct through their lives (Petrushenko, 2001, p. 126). Culture arises as a supernatural means of human life, as a mechanism of transformation of its animal existence into a social state (Kolesov, 1991, p. 13).

In descriptive definitions, culture is a clearly directed position of society, when the subordination of nature to man in the material and spiritual spheres supports the state of 
society, which harmonizes the relationship between man and nature, on the one hand, and on the other - ensures a harmonious balance of social relations. material and spiritual values.

\section{Table 1. Approaches to the definition of "culture"}

\begin{tabular}{|c|c|c|}
\hline Approach & Author, source & Definition \\
\hline \multirow{3}{*}{ 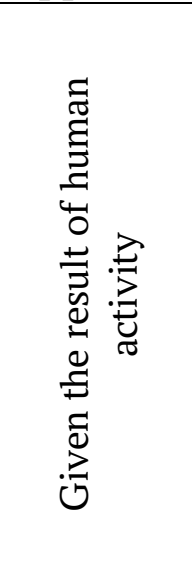 } & $\begin{array}{l}\text { V. Chernets } \\
(2012, p .3)\end{array}$ & $\begin{array}{l}\text { A holistic complex process, the main reference point of which is } \\
\text { man, his unconditional spiritual (moral and intellectual) develop- } \\
\text { ment and improvement. After all, the state of cultural development } \\
\text { of a country is one of the most objective indicators not only of the } \\
\text { spiritual health of society, but also the completeness of solving the } \\
\text { problems, especially political and economic, that face it. }\end{array}$ \\
\hline & $\begin{array}{l}\text { F. Moisieieva and } \\
\text { V. Usachov } \\
(2013, p .70)\end{array}$ & $\begin{array}{l}\text { A cumulative means of preserving the accumulated spiritual val- } \\
\text { ues, which has become sustainable. }\end{array}$ \\
\hline & $\begin{array}{l}\text { O. Batishcheva } \\
(2007, p .6)\end{array}$ & $\begin{array}{l}\text { The phenomenon of human civilization is a system of values and } \\
\text { cultural norms, their creation, selection, accumulation and retrans- } \\
\text { mission. }\end{array}$ \\
\hline \multirow{2}{*}{ 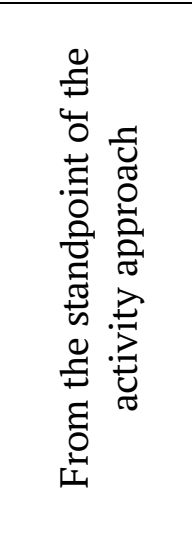 } & $\begin{array}{l}\text { L. Balashov } \\
(2005, p .456)\end{array}$ & $\begin{array}{l}\text { The set of knowledge and skills aimed at self-preservation, repro- } \\
\text { duction, improvement of man and embodied partly in the norms } \\
\text { of life (customs, traditions, canons, language standards, education, } \\
\text { etc.), partly in the subjects of material and spiritual culture. }\end{array}$ \\
\hline & $\begin{array}{l}\text { V. Petrushenko } \\
(2001, p .380)\end{array}$ & $\begin{array}{l}\text { The scope of the first and most expressive detection of man, his } \\
\text { essential characteristics and capabilities; part of reality trans- } \\
\text { formed by man, but in which human creative potential was mani- } \\
\text { fested with the greatest degree of completeness, perfection and ex- } \\
\text { pressiveness, as a result of which culture becomes the carrier of } \\
\text { manifestations of man as a man, i.e. the sphere of the first and } \\
\text { highest values, ideals, meanings. }\end{array}$ \\
\hline \multirow{3}{*}{ 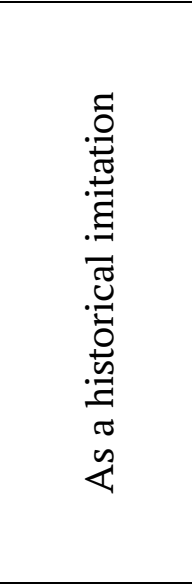 } & $\begin{array}{l}\text { M. Malovanyi } \\
(2013, p .158)\end{array}$ & $\begin{array}{l}\text { The process of emergence, interaction, change, preservation and } \\
\text { transmission of historically specific ways of activity in various } \\
\text { spheres of public life, during which the development of human } \\
\text { forces and relations, as well as man himself as a social object and } \\
\text { object of activity, which is expressed in all the richness and diver- } \\
\text { sity of the objective reality created by people, in the whole set of } \\
\text { results of human labour and thought. }\end{array}$ \\
\hline & $\begin{array}{l}\text { M. Kolesov } \\
(1991, p .13)\end{array}$ & $\begin{array}{l}\text { The supernatural means of human life as a mechanism of transfor- } \\
\text { mation of its animal existence into a social state. }\end{array}$ \\
\hline & $\begin{array}{l}\text { I. Ryzhova } \\
(2011, p .126)\end{array}$ & $\begin{array}{l}\text { A set of socially acquired and transformed from generation to gen- } \\
\text { eration significant symbols, ideas, values, customs, beliefs, tradi- } \\
\text { tions, norms and rules of conduct, through their lives. }\end{array}$ \\
\hline \multirow[b]{2}{*}{ 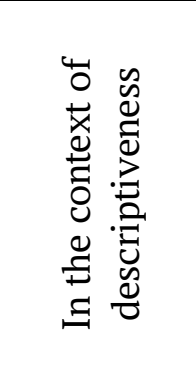 } & $\begin{array}{l}\text { K. Zablotska } \\
(2001, \text { p. 19) }\end{array}$ & $\begin{array}{l}\text { A phenomenon that makes people socially adapted, active and pro- } \\
\text { fessionally fit. }\end{array}$ \\
\hline & $\begin{array}{l}\text { V. Andrushchenko } \\
\quad(2014, p .7)\end{array}$ & $\begin{array}{l}\text { Clearly directed position of society, when the subordination of na- } \\
\text { ture to man in the material and spiritual spheres maintains the state } \\
\text { of society, which harmonizes the relationship between man and } \\
\text { nature, on the one hand, and on the other - provides a harmonious } \\
\text { balance of social relations between people, their different material } \\
\text { and spiritual values. }\end{array}$ \\
\hline
\end{tabular}

Source: systematized by the author. 
That is, cultural life is characterized by a certain ideal, homogeneous in its essence, which focuses on various forms of society (Andrushchenko, 2014, p. 7).

The broadest and most comprehensive concept is given by the authors of the "Philosophical Dictionary of Social Terms". It states that "culture" (from Latin - cultivation, development, upbringing, education, respect) is:

1) historically the original meaning - cultivation and care of the land;

2) care, improvement, ennoblement of physical, mental and spiritual strength, inclinations and abilities of man, and hence the degree of their development; respectively distinguish between body culture, soul culture and spiritual culture (already from Cicero we are talking about philosophy as a culture of spirit);

3) a set of ways and methods of organization, implementation and progress of human life, ways of human existence;

4) a set of material and spiritual possessions, expressing the historically achieved level of development of society and man, embodied in the results of productive activities;

5) localized in space and time socio-historical formation, which is divided either by historical types, or by ethnic, continental or regional characteristics of society. In the broadest sense, recorded by D. Vico, culture is what is created by man, in contrast to what is created by nature (Andrushchenko, 2002, p. 386).

Culture must be considered as a resource, bearing in mind that it becomes not only a costly area, but also the engine of the economy. Innovative commercial ventures that use culture as a resource are the fastest growing sector of the economy in many countries. In addition to traditional cultural institutions, the creative industries also include design, fashion, publishing, sound recording, multimedia technologies, and more. All these industries belong to the sphere of commercial culture and are not perceived in Ukraine as an independent integrated sector of the economy or as a subject of policy. Culture is a manifestation of the process of reproduction of human capital, es- pecially its psychological component. The experience of generations is concentrated in culture, knowledge, skills, abilities are preserved, built-in regulators of relations between people and structure of their labour efforts are formed and developed. The cultural level of citizens is largely determined by the policy pursued by the state in this area, taking into account the economic achievements of society, its sociopolitical, ideological, educational and spiritual and moral structures.

The concept of "politics" means primarily the activities of public authorities and public administration depending on the social structure and structure of the economic system of the country, as well as the way of action aimed at achieving a certain goal (Mochernyi and Skotnyi, 2006, p. 50). Thus, the policy is defined by the measures in relation to the previously performed tasks. Agreeing with the fact that structural policy as a management decision is the development of goals, objectives and mechanisms for their implementation, it should be emphasized that it contains not only public management decisions, but also the "activities of public authorities". Politics, because it contains objective and real content, contains economic and political relations, interests and forms of their manifestation in motion, material, personnel, financial, information resources.

With the development of society and changes in the structure of social production, intensification of certain economic processes, enriches and clarifies the meaning of "politics", increases its importance and the need to subordinate individual and group interests to the universal, which is to preserve the integrity and unity of society. It is important that today this special type of human activity is designed to clarify and ensure the long-term and current interests of different social groups. V. Bebyk notes that "modern traditions of using the term" politics "began with the ancient (ancient Greek) understanding of politics as a very noble cause - the art of public administration, designed to unite society around its highest goal" 
(Bebyk, 2003, p. 406). This indicates the provision of social processes and the development of a planning system in order to justify decisions, their regulation and movement in a certain direction.

Politics is a sphere of relationships between different social groups and individuals in the use of public authorities to realize their socially significant interests and needs (Yekhanurov and Rozputenko, 2001, p. 370). All this points to the relationship between the subjects of life in relation to the protection and realization of state interests, social order and law and order on the basis of production, distribution, exchange and consumption of various goods and services in society. Culture and traditions of individuals and communities, provision and possibility of receiving social and household services, possibility of interesting and useful use of free time and cultural rest create conditions to a certain attitude and desire to work, to intensify and increase labour efficiency to increase income in order to increase quantity and quality of meeting needs, improving the level and quality of life (Chukhno, 2015).

One can trace the purpose of politics as a sphere of human activity, which is manifested in the expression of the interests of different groups, which on the one hand - collide, and on the other - agree. The form of policy is embodied in certain areas, or organizational structure, with appropriate institutions, endowed with powers and ensure its stability, stability and able to regulate the behavior of participants in the process. If the essence of policy is management, it should be noted that in the most general sense of management (management) necessarily involves such components of the process as planning, organization, motivation and control necessary to achieve certain goals of management (Khudolii, 2013, p. 133).

Consideration of the content of the concepts of "culture" and "politics" as separate categories allowed to identify the general in order to proceed to the analysis of specific - state policy in the field of culture.
As the policy of the state is reflected in the functions, for the modern rule of law the main function is the protection of human interests, protection of human rights and freedoms, ensuring proper living conditions. Other functions of the state are to some extent subordinated to the implementation of its policy. Among them are the following: the creation of democratic conditions for the coordination of the interests of different social groups in society; creating conditions for the development of production; promoting the development of education, science, culture; environmental protection; protection of the constitutional order; ensuring law and order. That is, we are talking about state policy in various spheres of society, in particular, social, cultural, economic, regulatory, environmental, legal policy. Thus, the policy of the state is reflected in the direction of regulation of real social relations in life (Yakymets, 2011, p. 65).

State policy is developed and implemented by the state and its bodies, it provides the main directions of their activities and the activities in general in society and in a particular area, determines the internal course of the state and the principles of international activity (Karlova, 2003, p. 30). The Law of Ukraine "On Culture" states that the priorities of state policy in the field of culture are determined by:

- programs of the President of Ukraine, the annual message of the President of Ukraine to the Verkhovna Rada of Ukraine on the internal and external situation of Ukraine and programs of the Cabinet of Ministers of Ukraine, which must take into account aspects of cultural development;

- state target programs in the field of culture, which are developed and approved in accordance with the legislation;

- the program of activities of the central executive body that ensures the formation of state policy in the fields of culture and arts, the development of culture for the year, developed by the central executive body that ensures the formation of state policy in the fields of culture and arts and approved by the Cabinet of Ministers of Ukraine. 
The state as a matter of priority creates conditions for:

- development of culture of the Ukrainian nation, indigenous peoples and national minorities of Ukraine;

- preservation, reproduction and protection of the historical environment;

- aesthetic education of citizens, especially children and youth;

- expansion of rural cultural infrastructure;

- protection, promotion and support of cultural diversity as one of the most important factors of sustainable development of the state (The Verkhovna Rada of Ukraine, 2010).

Culture is the basis of the strategy of society development. Therefore, the issue of preserving cultural heritage are issues that today must not only be taken into account in theoretical considerations, discussions about the future of transformation processes in Ukraine, they are issues that should be a factor that will really affect the financial performance of cultural transformations in the country.

In accordance with the purpose and objectives of the budget program for 2018-2020, the Ministry of Culture of Ukraine has identified areas of activity:

- formation of an integral national linguistic and cultural space, filling it with highquality and diverse national cultural and artistic product;

- preservation and actualization of the national cultural heritage, its transformation into a real factor of social and economic development of Ukrainian society;

- ensuring the intensive development of domestic cultural industries through the formation of a regime of state protectionism for the national producer of cultural goods and services;

- integration of Ukrainian culture into the world cultural space, formation of a positive image of Ukraine in the world by means of culture;

- ensuring the development of leading art institutions and groups;
- expansion, development of competitive, grant mechanisms to support domestic art projects;

- providing conditions for meeting the national-cultural, linguistic and information needs of Ukrainians living outside Ukraine;

- ensuring the formation and implementation of state policy;

- implementation of the action plan for the implementation of the Public Finance Management System Reform Strategy for 2017-2020 and other instructions and programs of the Government;

- participation and implementation of tasks on reforming the ministry (Ministry of Culture of Ukraine, 2020).

The sphere of culture around the world is built on a combination of budgetary and extrabudgetary financing, within its limits there are various types of activity, a large amount of movable and immovable property, part of which is withdrawn from civil circulation or has restrictions on civil turnover (monuments, libraries, archives, museum collections, etc.).

The subject of state policy in the field of culture is not just certain groups of cultural institutions, theatres, museums, libraries, etc., but the whole set of regulated socio-cultural processes and interactions associated with the creation, preservation, dissemination of cultural values, their perception and leisure. . The main goal of state policy in the field of culture of an independent Ukrainian state is to promote the development and self-realization of the individual, humanization of society, establishment and development of a democratic Ukrainian state through revival, creation of a holistic national culture that would actively enter the world cultural space. support of cultural life of different national groups and cultural interests of citizens of Ukraine of different nationalities (Dziuba, 1998, p. 33). State policy in the field of culture is, first of all, certain relations of the state with the sphere of culture, as well as a set of legal principles, administrative, financial and other well-thought-out measures, activities and mechanisms that provide the basis of state and society in the field 
of culture. specific purpose. Regarding the support of financial support for culture, public policy has direct budget funding for current activities of institutions, organizations, cultural and artistic enterprises of state, communal, rarely private ownership and targeted transfers to finance national long-term programs and projects. Indirect measures of state support include state guarantees, credit and tax benefits.
Private financing of culture is carried out by attracting funds from patrons (corporate patronage and individual donations), sponsors and within public-private partnerships. In Ukraine, there is a system of mainly state support for financial support of culture, formed from direct and indirect budget funding (Dubok, 2015, p. 64) (Figure 1).

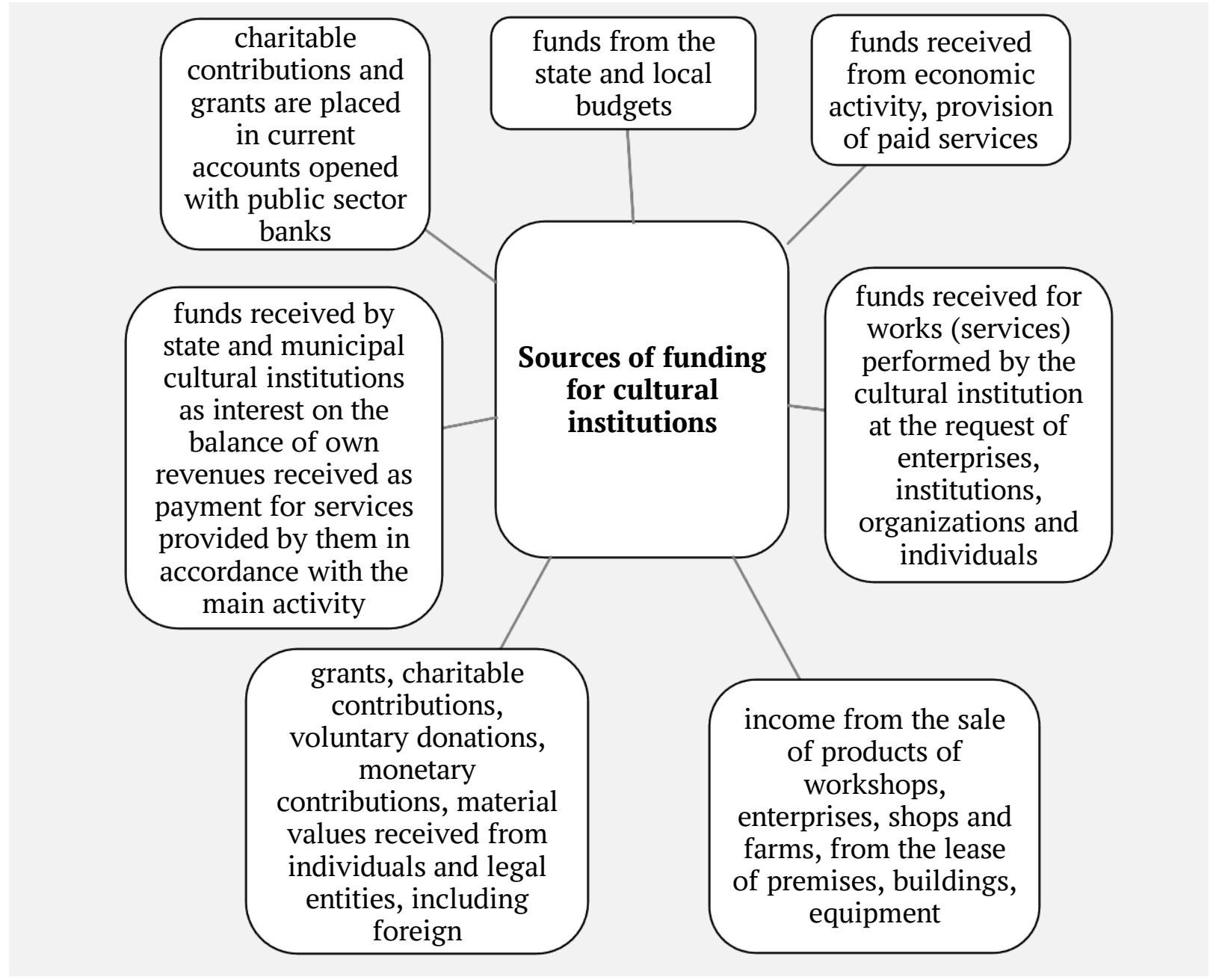

Fig. 1. Sources of funding for cultural institutions in Ukraine

Source: systematized by the author (The Verkhovna Rada of Ukraine, 2010).

In most developed European countries, budget funding remains one of the main forms of support for culture and the arts. However, the cost of these needs in budgets of countries are a relatively small part - from $0.2 \%$ to $2.5 \%$. The model of state financing of culture is formed in each country on the basis of a choice of methods, forms and mechanisms of financial policy. The functions of culture, in terms of their socio-economic content, form the spiritual enrichment of man and its impact on the final economic results. The goals of the state policy in the social sphere include support for the activities of non-governmental educational and cultural institutions. The cultural complex is a set of enterprises, institutions and organizations that solve specific problems of development and self-realization of the individual, 
the humanization of society and the preservation of the identity of peoples. In economic terms, entrepreneurship in the field of culture is no different from entrepreneurship in other areas. In most countries, the development of culture is considered in the context of small and medium enterprises, which in all countries has its own special status in one form or another - a simplified taxation system, benefits in access to public procurement, advisory and information services on various preferential terms. Therefore, in general, culture should be developed through the creation of a favourable "general" business environment and special cultural programs (Burakovskyi, 2019).

According to the legislation of Ukraine on culture, the basis of state guarantees for the preservation and development of culture is state funding.

The amount of annual expenditures of the Consolidated Budget of Ukraine for culture and art are presented in Figure 2.

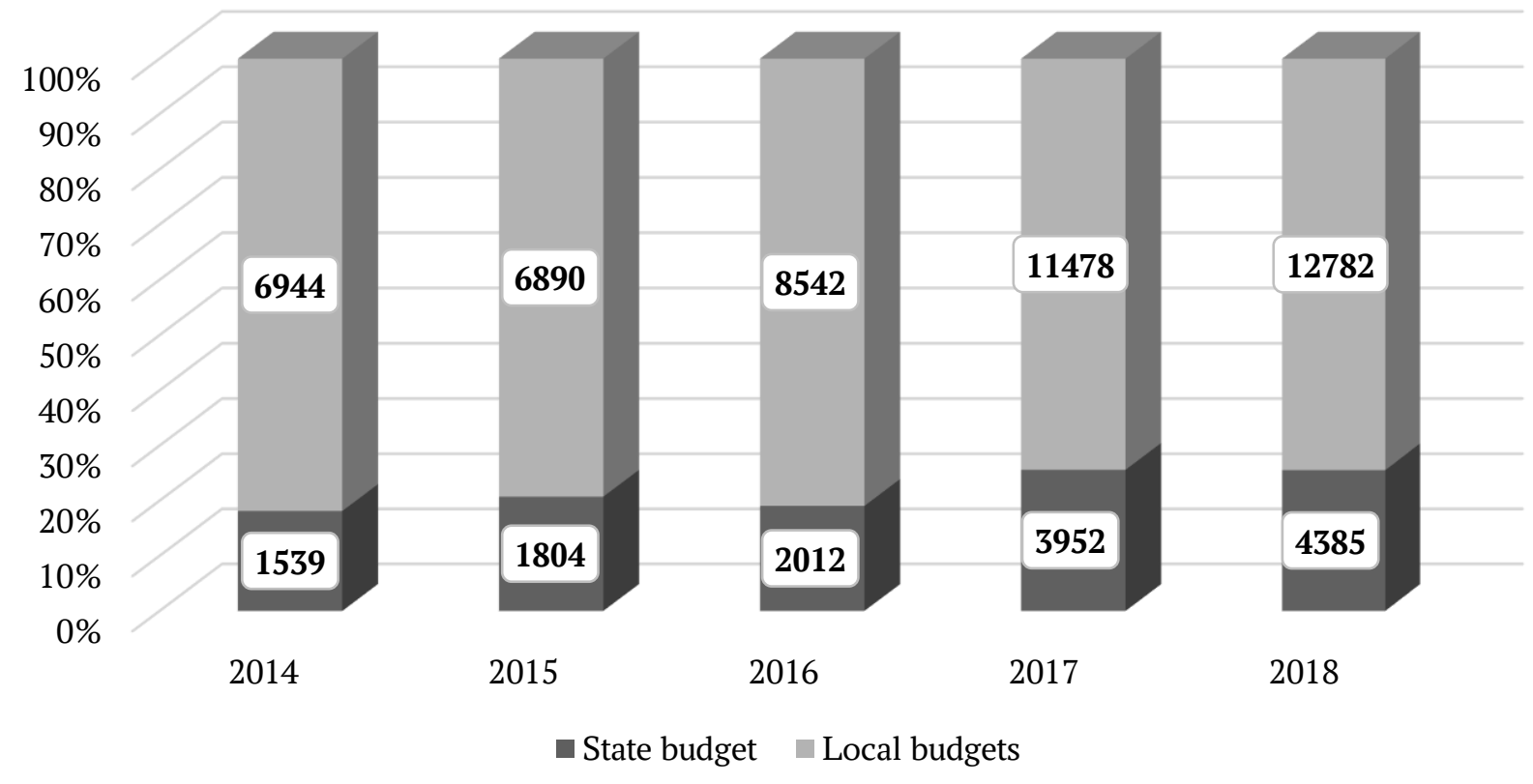

\section{Fig. 2. Expenditures of the Consolidated Budget of Ukraine for culture and art 2014-2018 (million UAH)}

Source: author's calculations.

The dynamics of budget expenditures on culture and art indicates the desire of government agencies to support segments of cultural life. Although it should be noted that the main costs of culture are the payment of wages involved in this area, at the same time there is a fact of increasing the social status of workers.

In order to financially support and protect institutions, enterprises and cultural organizations in a market economy, the targeted use of funds allocated for cultural needs, local cultural funds can be created.

Public associations, institutions, enterprises, organizations and citizens have the right to independently and on a contractual basis to create charitable foundations to finance cultural programs, development of literature and art, support of talents and creative endeavors in the field of culture, solving social and everyday problems of creative workers. (United Nations Educational, Scientific and Cultural Organization, 1982). The state implements a policy of preferential taxation in the field of culture: exempts from taxes creative unions, national-cultural societies, foundations, associations, other public associations operating in the field of culture, as well as cultural institutions that are fully or partially financed from the budget or funds of enterprises and trade unions; establishes benefits for the taxation of income of enterprises and organizations, individuals who partially deduct it for 
the needs of culture, provides benefits for the taxation of other payers (The Verkhovna Rada of Ukraine, 2010). In recent years, budget funding for culture and the arts has grown, although it has remained modest by European standards (Dolomanova, 2012, p. 178).

The low prestige of professions in this field is a big problem. Most enterprises that organize their activities in the field of culture and arts, in today's conditions focus on the trends of "survival", so the development of certain tasks aimed at effective state regulation of economic mechanisms that would stimulate their development should become one of the cultural policy . The solution of certain tasks related to the development of culture, the promotion of innovation in education, it is very difficult to specify in the form of activities that are not based on proposals, projects, programs of those who are ready to deal with these tasks directly. The policy objectives identified in this area and the measures supported cannot be based solely on theoretical knowledge, whatever it may be. In this aspect, it is advisable to interact with commercial and non-commercial organizations, "industry" and specially oriented units of government agencies. The first are the divisions of art, development and education, culture, and so on. The latter include, for example, the public relations departments of regional and local administrations.

Analysis of the socio-economic state of culture in Ukraine allows us to note about:

- deterioration of work culture;

- change of labour motivation, transformation of work in the field of culture into a factor of survival;

- reduction of the quality of labour potential due to non-profitability;

- decrease in interest in self-development and self-education;

- narrowing of the constitutional functions of the state in relation to ensuring and protecting the rights of citizens in the social sphere.

\section{Conclusions.}

For further effective assessment of the cultural development of society requires a special system of national indicators in the form of thresholds for the admissibility of their deviation, ranking according to the degree of urgency of state intervention. Modern economic development of the state in the conditions of global competition provides not only use of the state mechanisms, but also introduction of innovations, active realization of human capital. The strategic goals of the modern state should be focused on the use of innovative technologies and the potential of human capital. The quality of human capital determines the level of development of the modern economy. Developed countries are characterized by a high level of human capital. Therefore, it is important to increase spending on education and health care systems in order to form quality human capital in general and in the field of culture in particular. The quality of life includes a wide range of phenomena: the scale and nature of employment and working conditions, the level of education and literacy, the level of consumption of cultural and entertainment facilities, housing and its amenities, social security system, health care, environmental living conditions. The parameters of the quality of economic life are closely related to the parameters of the quality of the population itself, which contain not only physiological but also socio-moral characteristics of the population (motivation for highly productive work, education). Without full-scale investment in culture, it is impossible to achieve sustainable intellectual development of society. This is directly related to improving the quality of services to the population in the field of culture, the introduction of an evaluation system and criteria for economic efficiency of cultural expenditures.

In previous years, Ukraine created conditions for the development of a market economy, freedom of creativity and entrepreneurship, and competition. This contributed to socio-economic development, but at the same time the years of reforms and then the global financial and economic crisis led to certain consequences in the social sphere, causing defeats in science, education and culture. Deep 
systemic changes are needed, which should be based not only on indicators of financing culture, but also will encourage rethinking the role of culture in society, the role of the state in culture, defining the limits of responsibility for the cultural life of the country. Policy review in terms of public funding for culture and the arts should be based on certain performance areas that are a manifestation of the real cultural needs of society. The development of culture in Ukraine should be one of the most important strategic directions of state policy.

\section{References}

Andrushchenko, V. P. (2002), Filosofskyi slovnyk sotsialnykh terminiv [Philosophical dictionary of social terms], Korvin, Kharkiv, Ukraine, 672 c.

Andrushchenko, V. P. (2014), "The concept of culture: philosophical discourse at the turn of the century", Visnyk Instytutu rozvytku dytyny. Seriia: Filosofiia, pedahohika, psykholohiia, vol. 33, pp. 5-9.

Balashov, L. E. (2005), Filosofiya [Philosophy], Dashkov i Ko, Moskow, Russia, 672 p.

Batishcheva, O. S. (2007), "State management of the national culture development in the context of globalization", Ph.D. Thesis, Theory and history of public administration, National Academy for Public Administration under the President of Ukraine, Kyiv, Ukraine.

Bayanova, A. R., Vodenko, K. V., Sizova, Zh. M., Chistyakov, A. A., Prokopyev, A. I. and Vasbieva, D. G. (2019), “A philosophical view of organizational culture policy in contemporary universities", European Journal of Science and Theology, vol. 15, no. 3, pp. 121-131.

Bebyk, V. M. (2003), Politolohiia dlia polityka i hromadianyna [Politology for politicians and citizens]. MAUP, Kyiv, Ukraine, $424 \mathrm{p}$.

Burakovskyi, I. (2019), "Culture is the same kind of economic activity as any other", The Institute for Economic Research and Policy Consulting, available at: http://www.ier.com.ua/ua/publications/comments?pid=6230 (Accessed 29 September 2020).

Chernets, V. H. (2012), "State and culture: ontological aspect”, Visnyk Derzhavnoi akademii kerivnykh kadriv kultury i mystetstv, no. 4, pp. 3-8.

Chukhno, I. A. (2015), "Economic situation as a basis for public administration of socio-economic development of the region", Derzhavne upravlinnia: udoskonalennia ta rozvytok, [Online], no. 3, available at: http://nbuv.gov.ua/UJRN/Duur_2015 310 (Accessed 29 September 2020).

Committee of the Verkhovna Rada of Ukraine on Humanitarian and Information Policy (2019), "Information on budget funding of culture and art", available at: http://kompkd.rada.gov.ua/uploads/documents/31985.pdf (Accessed 29 September 2020).

Csorba, L. (2020), “The determining factors of financial culture, financial literacy and financial behavior”, Public Finance Quarterly, no. 1, p. 67-83. doi: https://doi.org/10.35551/PFQ 202016

Dolomanova, K. Yu. (2012), "Current problems of financing the field of "Culture and Arts" in terms of development budget and consumption budget", Visnyk Donetskoho universytetu ekonomiky ta prava, no. 2, pp. 177-184.

Dubok, I. P. (2015), "Sources of funding for culture in Ukraine and directions for their expansion", Visnyk Natsionalnoi akademii derzhavnoho upravlinnia pry Prezydentovi Ukrainy, no. 2, pp. 63-70.

Dziuba, I. M. (1998), Mizh kulturoiu i politykoiu [Between culture and politics], Sfera, Kyiv, Ukraine, 372 p.

Honcharenko, S. (1997), Ukrainskyi pedahohichnyi slovnyk [Ukrainian pedagogical dictionary], Lybid, Kyiv, Ukraine, $366 \mathrm{p}$.

Ihnatchenko, I. H. (2013), "Features of the implementation of state policy of Ukraine in the field of culture: current status and world standards", Teoriia i praktyka pravoznavstva, [Online], vol. 1, available at: http://nbuv.gov.ua/UJRN/tipp 2013116 (Accessed 29 September 2020).

Karlova, V. V. (2003), "Public policy in the sphere of culture: essense and the peculiarities of putting it into effect in modern conditions", Abstract of Ph.D. dissertation, Theory and History of Public Administration, Ukrainian Academy of Public Administration, Office of the President of Ukraine, Kyiv, Ukraine, $180 \mathrm{p}$.

Khudolii, M. V. (2013), "Cultural policy: basic approaches to the definition", Visnyk Natsionalnoi akademii kerivnykh kadriv kultury i mystetstv, no. 4, pp. 132-136.

Kolesov, M. S. (1991), Chelovek i kul'tura: filosofskie razmyshleniya [Human and culture: philosophical reflections], Znanie, Kyiv, Ukraine, 48 p.

Lavezzolo, S., Rodríguez-Lluesma, C. and Elvira, M. (2018), "National culture and financial systems: The conditioning role of political context", Journal of Business Research, vol.85, pp.60-72. doi: https://doi.org/10.1016/j.jbusres.2017.12.021 
Malovanyi, M. M. (2013), “Culture as a social phenomenon (methodological and methodological aspect of consideration)", Horyzonty osvity, no. 3, pp. 154-163.

Ministry of Culture of Ukraine (2020), "Documents", available at: http://mincult.kmu.gov.ua/control/uk/publish/officialcategory?cat id=99797 (Accessed 29 September 2020).

Mochernyi, S. V. and Skotnyi, V. H. (2006), Osnovy ekonomichnoi teorii [Fundamentals of economic theory], Novyi svit-2000, Lviv, Ukraine, 600 p.

Moisieieva, F. A. and Usachov, V. A. (2013), “ Understanding culture as a process of human society development”, Nauka. Relihiia. Suspilstvo, no. 4, pp. 70-74.

Nocca, F. (2017), "The role of cultural heritage in sustainable development: Multidimensional indicators as decision-making tool", Sustainability, 9(10). doi: https://doi.org/10.3390/su9101882, available at: https://www.mdpi.com/2071-1050/9/10/1882/htm (Accessed 29 September 2020).

Petrushenko, V. L. (2001), Filosofiia [Philosophy], Karavela, Kyiv, Ukraine, 448 p.

Ryzhova, I. S. (2011), "Culture as the most fundamental way of human existence”, Humanitarnyi visnyk Zaporizkoi derzhavnoi inzhenernoi akademii, vol. 46, pp. 126-134.

The Verkhovna Rada of Ukraine (2010), The Law of Ukraine “On culture", available at: https://zakon.rada.gov.ua/laws/show/2778-17 (Accessed 29 September 2020).

Tian, M., Deng, P., Zhang, Y. and Salmador, M. P. (2018), "How does culture influence innovation? A systematic literature review”, Management Decision, vol. 56, no. 5, pp. 1088-1107. doi: https://doi.org/10.1108/MD$\underline{05-2017-0462}$

United Nations Educational, Scientific and Cultural Organization (1982), Recommendation No. 119 of the World Conference on Cultural Policy "Governance in the field of culture. Establishment of bodies dealing with cultural issues”, available at: https://zakon.rada.gov.ua/laws/show/995 756\#Text (Accessed 29 September 2020).

Yakymets, Yu. V. (2011), "State policy in the sphere of culture", Naukovyi visnyk Natsionalnoi akademii vnutrishnikh sprav, no. 6, pp. 64-69.

Yekhanurov, Yu. and Rozputenko, I. (eds.) (2001), Ekonomichnyi rozvytok i derzhavna polityka [Economic development and public policy], UADU, Kyiv, Ukraine, $480 \mathrm{c}$.

Zablotska, K. V. (ed.) (2001), Ukrainska ta zarubizhna kultura [Ukrainian and foreign culture], Skhid, Donetsk, Ukraine, $372 \mathrm{p}$.

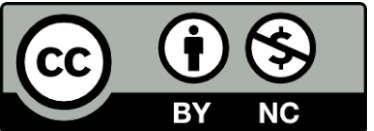

Цей твір ліцензовано на умовах Ліцензії Creative Commons «/з Зазначенням Авторства - Некомериійна 4.0 Міжнародна» (CC BY-NC 4.0).

This is an open access journal and all published articles are licensed under a Creative Commons "Attribution-NonCommercial 4.0 International" (CC BY-NC 4.0). 